\title{
Knowledge and Practices of the residents living along the Nairobi River Riparian on the use of the contaminated river for farming and its effects on animal reproduction
}

\author{
Kipyegon AN ${ }^{*}$, HM Mutembei, VT Tsuma JA Oduma ${ }^{1}$ and P Kimeli \\ Department of Clinical Studies, ${ }^{l}$ Department of Veterinary Anatomy and Physiology, \\ Faculty of Veterinary Medicine, University of Nairobi, P.O. Box 29053-00625 Kangemi, Kenya
}

\begin{abstract}
Residents practising pig farming along the Nairobi River Riparian in Kenyawere interviewed to evaluate theirknowledge and practices on the use of the contaminated riverfor farming and its effects on animal reproduction. Eighty (80) farms were purposively selected and questionnaires administered to the pig owners as respondents.Majority (72.5\%) were involved in urban farming as supplementary source of income while the rest had farming as their main occupation. Over a third of them (38.8\%) had attained secondary level of education. Over forty percent $(42.5 \%, N=34)$ respondents used the contaminated river for pig farming. The main reason cited for the use of the river water for farming were that it is a free source and readily available $(N=20)$.The main reproductive effect noted on the male pigs was abdominally testes. The reproductive defect points towards environmental estrogen toxicant within the water of the Nairobi riversuggesting the residents need to be made aware of the potential danger of the use of the contaminated water for farming.
\end{abstract}

\section{Introduction}

Farming is an important activity in many urban residences of the world (Lee-Smith, 2010).In African cities, an average of $35 \%$ of households engage in agriculture (Nabuloet al., 2006) for food security, employment and re-use of wastes (Drechselet al., 2002). In Kenya, urban farming was identified as a response to limited alternative livelihood options.In urban farming river water; most often contaminated, is an important source of water (Drechselet al., 2002) despite the health and environmental risk associated with its use.

Informal settlements often lack connectivity to sewerage facility hence substantial volumes of domestic and industrial wastewater is dischargedinto surface water. Urban rivers are for this reason heavily polluted with toxic contaminants likely to affect users of such water. In many cities, urban livestock farming takes place in densely populated neighbourhoods and characterised by free range systems which require low inputs. The animals kept include ruminants, pigs, chicken, ducks, dogs and cats (Lupala, 2002). Among these, Pig farming is the most remarkable in urban slum areas of developing countries. Pigs are spotted rooting in garbage disposal points, wastewater drainage channels and rivers. Due to this, exposure to pollutants is possibly very high.

Urban draining rivers have been reported to be contaminated with Endocrine disrupting chemicals (Kolpinet al., 2002) which are associated with adverse reproductive defects in aquatic organisms (Hecker et al., 2002). In ruminants, adverse reproductive effects were reported on lambs whose mothers were exposed to lowlevel doses of a variety of compounds in sewage sludge (Paul et al., 2005).

This study aimed at investigating the knowledge and perception of urban informal settlement pig farmers on the use of wastewater or effluent contaminated water on the reproductive health of boars.

\section{Study area}

\section{Materials and method}

The study was carried out in the informal settlements in Nairobi city, Kenya. The sites selected were Kibera, Mathareand Dandora. These locations were selected for the study for three main reasons; proximity to a city river, the physical appearance of the water and a high number of small holder pig keeping activities, with the animals scavenging in wastewater canal and polluted rivers.

\section{Study design and data management}

This was a cross-sectional study in which selected households were visited once for interview. A total of 80Pig farms in informal settlementsalong the Nairobi River riparian were purposively selected for this study. A semi structured questionnaire was used to obtain information from the willing pig owners livingnot more than 50 metres from a visibly polluted river.An adult member of the family was picked as a respondent based on willingness to take the interview; this was regardless of the education status, gender and occupation. The interview aimed at establishing the use of contaminated water for pig farming and the knowledge on any noticed pig reproductive.Data collected were entered and later analysed using Microsoft office excel. 
Knowledge and Practices of the residents living along the Nairobi River Riparian on the use of the..

\section{Results}

Among the persons interviewed $21(n=21)$ lived inKibera informal settlement, $21 \quad(n=21)$ lived in Dandora and $38(n=38)$ lived inMathare informal settlement. All were male and over thirty percent $(38.8 \%)$ had attained secondary level of education. Over seventy percent $(72.5 \%)$ were involved in urban pig farming as supplementary source of income while the rest practised pig farming as their main source of income (Table 1)

Table 1:Characteristics of the respondents surveyed

\begin{tabular}{|l|l|l|l|}
\hline Variable & Category & Frequency & Percentage \\
\hline \multirow{4}{*}{ Location } & Kibera & 21 & 26.3 \\
\cline { 2 - 4 } & Mathare & 38 & 47.5 \\
\cline { 2 - 4 } & Dandora & 21 & 26.3 \\
\hline \multirow{5}{*}{ Education status } & Primary & 24 & 30.0 \\
\cline { 2 - 4 } & Secondary & 31 & 38.8 \\
\cline { 2 - 4 } & Tertiary & 2 & 2.5 \\
\cline { 2 - 4 } & Undisclosed & 23 & 28.8 \\
\hline Occupation & Full time farming & 22 & 27.5 \\
\cline { 2 - 4 } & Part time farming & 58 & 72.5 \\
\hline
\end{tabular}

Among the people interviewedover forty percent $(42.5 \%, \mathrm{n}=34)$ respondents used contaminated river water for pig farming, the majority of which $(n=21)$ being from kibera while the rest $(n=13)$ were from Dandora. Those others, mainly from Mathare usedclean tap water for pig farming (Table 2).

Table 2:Preferredwater source for pig farming among the respondents

\begin{tabular}{|l|l|l|}
\hline Location of Informal settlement & River/wastewater & Tap water \\
\hline Kibera & $21(61.8)$ & $0(0 \%)$ \\
\hline Mathare & $0(0 \%)$ & $38(82.6 \%)$ \\
\hline Dandora & $13(38.2 \%)$ & $8(17.4)$ \\
\hline
\end{tabular}

Out of those farmers who used contaminated river water for pig farming, $14(n=14)$ cited the reason for the use as being a free source while $20(n=20)$ indicated also it was free and readily available (Table 3 ).

Table 3: Reasons given for use of contaminated water for pig farming

\begin{tabular}{|l|l|l|}
\hline \multirow{2}{*}{ Location of informal settlement } & \multicolumn{2}{|l|}{ Reasons for preferred source of water } \\
\cline { 2 - 3 } & Free source of water & Easily accessible \\
\hline Kibera & $10(58.8 \%)$ & $11(44 \%)$ \\
\hline Mathare & $3(17.6 \%)$ & $5(20 \%)$ \\
\hline Dandora & $4(23.5 \%)$ & $9(36 \%)$ \\
\hline
\end{tabular}

The reproductive problem of abdominally retained testes was reported among the farms of respondents using contaminated water. The occurrence of retained testis was significantly higher $(\mathrm{p} \leq 0.05, \mathrm{n}=22)$ in farms using contaminated river water(Table 4).

Table 4: Table showing the male defects reported in relation to the water source

\begin{tabular}{|l|l|l|l|}
\hline \multirow{2}{*}{ Water source } & Male defects & \multirow{2}{*}{ Total } \\
\cline { 2 - 3 } & None & Retained testis & 34 \\
\hline Contaminated river water & $12(23.1 \%)$ & $22(78.6 \%)^{\mathrm{a}}$ & 34 \\
\hline Tap water & $40(76.9 \%)$ & $6(21.4 \%)^{\mathrm{b}}$ & 46 \\
\hline Total & 52 & 28 & 80 \\
\hline
\end{tabular}

$A$ is significantly higher than $b(\mathrm{p} \leq 0.05)$

\section{Discussion}

Access to contaminated river water has been shown to cause various health and reproductive problems (Bellinghanet al., 2012). In this study, the main finding reported by the respondents is the problem of abdominally retained testes for the male pigs farmed using contaminated river water. This finding confirms earlier reports of similar reproductive abnormalities of testicular retention. Paul et al (2005) demonstrated that prolonged exposure of ewes to water contaminated with sewage caused a disruption of testicular growth. Similarly, Svechnikovet al (2014) indicated there is increased risk of having cryptochid sons from mothers occupationally exposed to such contaminated water. This finding points towards effects of estrogen toxicant within the contaminated water, as previous students of Svechnikov et al. (2014) demonstrated.

Endocrine disrupting chemicals with anti-androgenic (Stoker et al., 2005) or estrogenic effects (Main $e t$ al., 2007) have the potential of disturbing cellular events that control the testicular descent in humans (Svechnikovet al., 2014). Consequently, sewage has been shown to contain a complex mix of several 
Knowledge and Practices of the residents living along the Nairobi River Riparian on the use of the..

chemicals(Paulet al., 2005) which include these EDC and thus the potential to cause testicular retention upon prolonged exposure.

The respondents identified the ease of availability, convenience and no cost attached to its use as the main reasons for using contaminated river water to practise pig farming. Similar reasons have been reported before by those who used contaminated river water for irrigation (Ndunda and Mungatana 2013).

Conclusion

The reproductive defect reported by this study points towards environmental estrogen toxicant within the water of the Nairobi river suggesting the residents need to be made aware of the potential danger of the use of the contaminated water in farming.

\section{References}

[1]. Bellingham M, McKinnell C, Fowler PA, Amezaga M. R, Zhang Z, Rhind SM, Cotinot C, Mandon-Pepin B, Evans NP and Sharpe RM 2012. Foetal and post-natal exposure of sheep to sewage sludge chemicals disrupts sperm production in adulthood in a subset of animals. International Journal of Andrology, 35, 317-329

[2]. Drechsel P, Blumenthal UJ, Keraita B 2002. Balancing health and livelihoods: adjusting wastewater irrigation guidelines for resource-poor countries. Urban Agriculture Magazine 8, 7-9.

[3]. Hecker M, Tyler CR, Hoffmann M, Maddix S, Karbe L 2002. Plasma biomarkers in fish provide evidence for endocrine modulation in the Elbe River, Germany. Environ. Sci. Technol. 36, 2311-2321.

[4]. Kolpin DW, Furlong ET, Meyer MT, Thurman EM, Zaugg SD, Barber LB, Buxton HT 2002. Pharmaceuticals, hormones, and other organic wastewater contaminants in U.S. streams, 1999-2000: A national reconnaissance. Environ. Sci. Technol. 36,1202-1211.

[5]. Lee-Smith D 2010. Cities feeding people: an update on urban agriculture in equatorial Africa Environment \& Urbanization 22(2): 483-499

[6]. Lupala A 2002. A scoping study on urban and peri-urban livestock keeping in Dar es Salaam, UCLAS Consultancy Unit, Tanzania. Rhind SM. 2002. Endocrine disrupting compounds and farm animals: their properties, actions and routes of exposure. Domestic Animal Endocrinology 23, 179-187.

[7]. Main KM, Kiviranta H, Virtanen HE, Sundqvist E, Tuomisto JT, Tuomisto J, Vartiainen T,Skakkebaek NE, Toppari J2007. Flame retardants in placenta and breastmilk and cryptorchidism in new born boys. Environ. Health Perspect. 115, 1519-1526.

[8]. Nabulo G, Oryem-Origa H, Diamond M. 2006. Assessment of lead, cadmium, and zinc contamination of roadside soils, surface films, and vegetables in Kampala City, Uganda.Environ Res.; 101(1):42-52.

[9]. Ndunda EN, Mungatana ED 2013. Farmers' Perception and Knowledge of Health Risks in Wastewater Irrigation. Open Science Repository Natural Resources and Conservation, Online(open-access).

[10]. Paul C, Rhind SM, Kyle CE, Scott H, McKinnell C, Sharpe RM 2005. Cellular and Hormonal Disruption of Fetal Testis Development in Sheep Reared on Pasture Treated with Sewage Sludge. Environmental Health Perspectives 113 (11): $1580-1587$

[11]. SvechnikovK, Stukenborg JB, savchuck I, Soder O 2014. Simillar causes of various reproductive disorders in early life. Asian J. Androl. 16, 50-59

[12]. Stoker TE, Cooper RL, Lambright CS, Wilson VS, Furr J, Gray LE 2005. In vivo and in vitro anti-androgenic effects of DE-71, a commercial polybrominated diphenyl ether (PBDE) mixture.Toxicol. Appl.Pharmacol.207(1):78-88. 